\title{
Peertechz
}

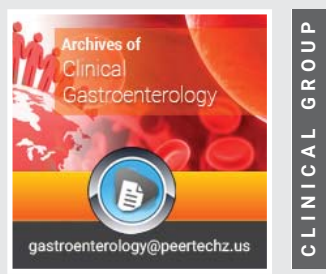

\section{The early phase of Crohn's disease in a young girl}

\section{Zhong-Xin Yang ${ }^{1,2}$, Wei-Wen Tang ${ }^{1,2}$ and Wei Liu ${ }^{1,2 *}$}

${ }^{1}$ Institute of Digestive Disease, China Three Gorges University, Yichang, China

${ }^{2}$ Department of Gastroenterology, Yichang Central People's Hospital, Yichang, China
NSN: $2455-2283$

DOI: https://dx.doi.org/10.17352/acg
Received: 17 May, 2021

Accepted: 07 June, 2021

Published: 08 June, 2021

*Corresponding author: Wei Liu, PhD, Institute of Digestive Disease, China Three Gorges University, 8 Daxue Road, Yichang 443000, China,

E-mail: liuwei@ctgu.edu.cn

https://www.peertechzpublications.com

Check for updates
A 21-year-old girl was transferred to our hospital with 1-year history of abdominal pain and vomiting that had progressed over the preceding 3 weeks. She had presented to the local hospital with a 3-day history of fever before presentation. Physical examination revealed normal vital signs and mild periumbilical tenderness with active bowel sounds. Laboratory tests of the blood confirmed a white-cell count of 13,400 per cubic millimeter (reference range, 4000 to 10,000). Computed Tomography (CT) of the abdomen revealed lymphnode enlargement of ileocecal region. Colonoscopy revealed aphthous ulcer and erosion of both terminal ileum and rectum by Linked Color Imaging (LCI), a novel image enhanced endoscopy technology (Figure 1A-C), and findings on biopsy of colonic mucosa showed non-caseous granuloma and infiltration of both plasma cells and lymphocytes (Figure 1D).

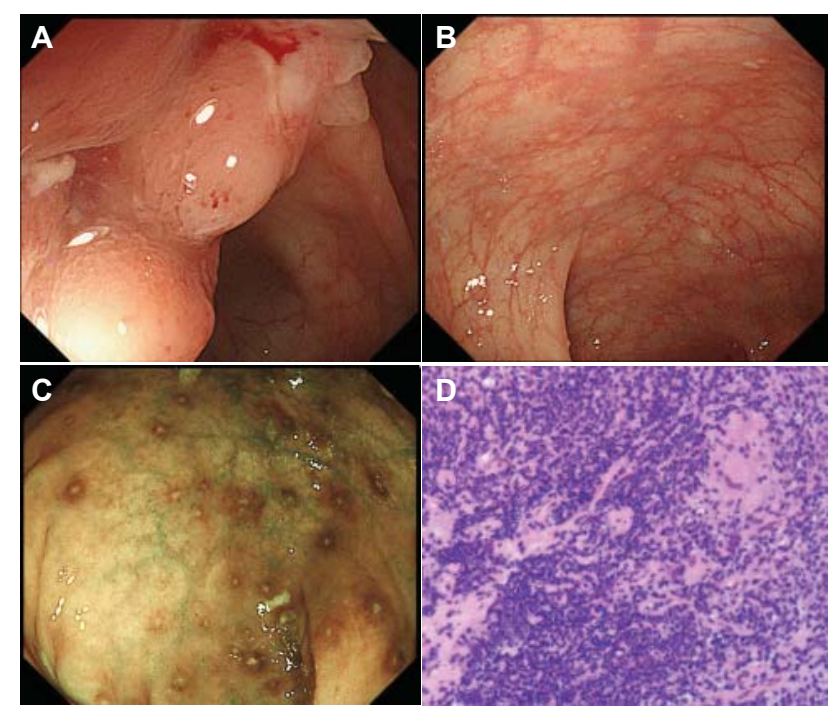

Figure 1: Colonoscopy revealed aphthous ulcer and erosion of both terminal ileum and rectum by linked color imaging ( $\mathrm{LCl}$ ), and findings on biopsy of colonic mucosa showed non-caseous granuloma and infiltration of both plasma cells and lymphocytes.
Considering the potentially associated lesions in the terminal ileum and rectum, CT enterography showed thickened terminal ileum wall (Figure 2A). Trans-anal double-balloon enteroscopy was assessed and confirmed numerous ulcers with the pecimen confirming longitudinal ulcers. Direct microbiologic detection and cultures were negative for tuberculosis and the human immunodeficiency virus. The early phase of Crohn's disease was considered to be the most plausible explanation, but the differential diagnosis of the terminal ileum and rectum lesions also included ulcerative colitis, tuberculosis and lymphoma. After a well-informed discussion of options for interventions with her father, the decision was made to pursue infliximab infusions of $5 \mathrm{mg} / \mathrm{kg} /$ dose at 0,2 , and 6 weeks and every 8 weeks thereafter. After the procedure, she clinically recovered with intermittent endoscopic surveillance and long-term clinical follow-up evaluation. The early diagnosis and treatment of Crohn's disease, acting as a complex and challenging clinical problem, is of great significance for promoting remission, enhancing therapeutic effect, reducing complications, preventing recurrence and improving quality of life [1,2]. Early diagnosis depends on clinical manifestations, endoscopy, pathology, laboratory, and imaging $[3,4]$. Treatment in the early phase of the disease strives for mucosal healing to improve the prognosis of Crohn's disease [5-7].

\section{Acknowledgements}

Funding: This work was supported by National Natural Science Foundation of China (31600134).

Ethical statement: The authors are accountable for all aspects of the work in ensuring that questions related to the accuracy or integrity of any part of the work are appropriately investigated and resolved. Written informed consent was obtained from the patient for publication of this "Images in Clinical Medicine". 


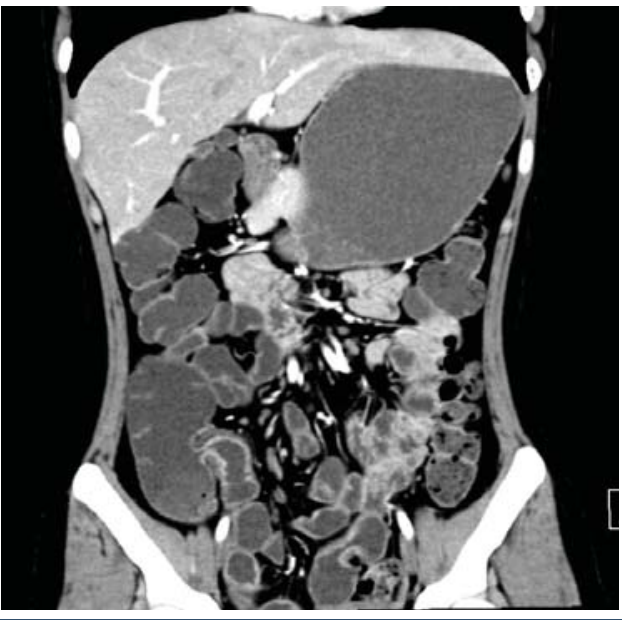

Figure 2: CT enterography showed thickened terminal ileum wall.

\section{Author's contributions}

Collection of data: Zhong-Xin Yang.

Manuscript preparation and writing: Wei-Wen Tang.

Final approval of the manuscript: Wei Liu.

\section{References}

1. Torres J, Mehandru S, Colombel JF, Peyrin-Biroulet L (2017) Crohn's disease. Lancet 389: 1741-1755. Link: https://bit.ly/3cmcuhB

2. Cushing K, Higgins PDR (2021) Management of Crohn Disease: A Review JAMA 325: 69-80. Link: https://bit.ly/3v2mEKC

3. Moazzami B, Moazzami K, Rezaei N (2019) Early onset inflammatory bowe disease: manifestations, genetics and diagnosis. Turk J Pediatr 61: 637-647. Link: https://bit.ly/2SeoNpe

4. Freeman HJ (2014) Natural history and long-term clinical course of Crohn's disease. World J Gastroenterol 20: 31-36. Link: https://bit.ly/2T8P4FK

5. Bamias G, Cominelli F (2020) Exploring the Early Phase of Crohn's Disease Clin Gastroenterol Hepatol. Link: https://bit.ly/3gc5Ds5

6. Louis E (2012) Epidemiology of the transition from early to late Crohn's disease. Dig Dis 30: 376-379. Link: https://bit.ly/3uXFjXW

7. Fascì Spurio F, Aratari A, Margagnoni G, Doddato MT, Papi C (2012) Early treatment in Crohn's disease: do we have enough evidence to reverse the therapeutic pyramid? J Gastrointestin Liver Dis 21: 67-73. Link: https://bit.ly/3pDXYHv

\section{Discover a bigger Impact and Visibility of your article publication with}

\section{Peertechz Publications}

\section{Highlights}

* Signatory publisher of ORCID

* Signatory Publisher of DORA (San Francisco Declaration on Research Assessment)

* Articles archived in worlds' renowned service providers such as Portico, CNKI, AGRIS, TDNet, Base (Bielefeld University Library), CrossRef, Scilit, J-Gate etc.

* Journals indexed in ICMJE, SHERPA/ROMEO, Google Scholar etc.

* OAI-PMH (Open Archives Initiative Protocol for Metadata Harvesting)

* Dedicated Editorial Board for every journal

* Accurate and rapid peer-review process

- Increased citations of published articles through promotions

Reduced timeline for article publication

Submit your articles and experience a new surge in publication services (https://www.peertechz.com/submission). 